\title{
EVALUATION OF HIGH SPEED DIESEL ENGINE PERFORMANCE AND CHARECTERISTICS OF ITS EMISSIONS WITH CARBON NANOTUBES ADDED ETHANOL-DIESEL BLENDS
}

\author{
N. VENKATESH, M. SRINIVASA RAO \& A. LAKSHUMU NAIDU \\ Department of Mechanical Engineering, GMRIT, Rajam, Andhra Pradesh, India
}

\begin{abstract}
The main criteria of this experimental work is to study and analyze the performance and emission characteristics of a high speed single cylinder 4 stroke kirloskar AVI Diesel engine with the carbon nanotubes, added with blends of ethanol and diesel. Ethanol could be blended with diesel easily, which is called as diesohol. The variation in performance parameters and emissions due to the addition of nanoparticles was studied by the experimentation. In this work, a 50ppm concentration of carbon nanotube (CNT) was added to the blends of ethanol and diesel to find out the variations when compared with diesel. Totally, three different types of blends were prepared, named as E1050CNT (ethanol 10\%, diesel 90\%,50ppm CNT), E2050CNT (ethanol 20\%, diesel 80\%,50ppm CNT) and E3050CNT (ethanol $30 \%$, diesel 70\%,50ppm CNT) to measure the performance parameters like Specific fuel consumption(SFC), Brake thermal efficiency(BTE) and characteristics of emissions like $\mathrm{CO}, \mathrm{HC}, \mathrm{CO}_{2}$ and $\mathrm{NO}_{X}$ at a constant speed of 1500 rpm at various loads of $3 \mathrm{~kg}, 6 \mathrm{~kg}$, $9 \mathrm{~kg}$ and $12 \mathrm{~kg}$ to make comparison with diesel. When the results compared with diesel, the $\mathrm{SFC}$ was increased, $\mathrm{BTE}$ is slightly reduced and the emissions like $\mathrm{CO}, \mathrm{HC}$ and $\mathrm{CO}_{2}$ were decreased, but $\mathrm{NO}_{\mathrm{X}}$ was slightly increased with the nano-ethanol-diesel blends. The results from the experiment shows that the desired conditions of performance parameters like SFC and BTE were obtained with E10CNT50 blend, and a significant decrease in emissions was obtained with E30CNT50 blend. Finally, it is recommended to use the nano-ethanol-diesel blends for a diesel engine, as an acceptable and suitable alternative fuel without any modifications.
\end{abstract}

KEYWORDS: Diesel Engine, Ethanol, Performance, Emissions \& Blends \& CNT

Received: Jul 17, 2017; Accepted: Aug 05, 2017; Published: Aug 21, 2017; Paper Id.: IJMPERDAUG201744

\section{INTRODUCTION}

Now days, the usage of Diesel engines are highly increased in the sectors like power generation, automobiles, agriculture, industries and large machineries because of its better efficiency, reliability and economy. In the present day to day situations, the whole world is facing the two problems globally. One is the fast depletion of conventional petroleum fuel resources and another one is nonstop increase of pollution in the environment. When working on diesel engines, it is very serious problem to control the emissions of oxides of nitrogen due to achieving of higher temperatures during heavy loads. To reduce the air pollution along with no compromise in required needs and demands of energy sectors, it is very essential to go for an alternate fuel to replace the fossil fuels. Due to these reasons, the researchers are showing their interest to find out the chances of producing alternate fuels. For this, the fuels from agricultural biomass and solid waste are the proper renewable resources to prepare alternative fuels. There by, it is possible to reduce the effects of global warming, environmental pollution, energy costs and demand of energy needs. These bio fuels could be produced from waste oils, animal fats, municipal 
solid, plant and forest wastes. These bio fuels can be easily blended with diesel, by adding it directly on volume basis to make several blends for automobiles, home heating requirements and industry requirements. The properties of biodiesels are very similar to diesel and don't contain impurities like sulphur and aromatics. Therefore, these bio fuels can be replaced for diesel in diesel engines directly, by without doing any major changes and modifications to the engine. Khadijeh Heydari et al performed an experiment with CNT added diesohol blends to analyze its emissions and performance on a diesel engine. From their experiment, the results show that the Brake thermal efficiency was increased by $13.97 \%$ with E4B2C60, when compared with conventional diesel. The SFC and temperature of exhaust gases were decreased by 11.73 and $1.86 \%$. Whereas, the other emissions like $\mathrm{HC}, \mathrm{CO}$ were reduced by 31.72 and $5.47 \%$, but the $\mathrm{NO}_{\mathrm{X}}$ was raised by $12.22 \%$. Another researcher Ahmed I. El-Seesy conducted an experiment with the blends of biodiesel, diesel with the additive multiwall CNT. Their results showed that the BTE was increased by $16 \%$ with MWCNT-B20 blend along with improvement in combustion, and the emissions like $\mathrm{NO}_{\mathrm{x}}, \mathrm{HC}$ and $\mathrm{CO}$ were considerably decreased by 35,50 and $60 \%$.R. Parthasarathi et al investigated on the diesel engines with the blends of diesel-ethanol emulsions to find out the emission characteristics and its performance. They got the results as with E40D50, the SFC was decreased and BTE was increased, but the $\mathrm{HC}$ and $\mathrm{NO}_{\mathrm{x}}$ emissions were greater when compared with diesel and the smoke density is lighter and carbon dioxide emissions are lesser.[1-6]

Arul Mozhi Selvan et al have done the work on a diesel engine by diesel- biodiesel-ethanol blends with additive cerium oxide nano particle. From their investigation it was found that by making ultrasonication to the blends, the stability of the blends is increasing and to avoid layer separation in a blend, additive castor oil methyl oil can be used. Emissions were reduced due to the mixing of nano particles and improve the combustion rate. Yanuandri Putrasari et al also performed the experiment with the ethanol-diesel blends in a volume proportion of 2.5, 5, 7.5, and 10 at various loads [710]. Their results indicate that by increasing the percentage of ethanol in the fuel blends, the diesel engine power was increased and the SFC exhaust gas temperatures were decreased, and the exhaust gases like CO, HC and smoke were reduced. S. Gomasta and S.K. Mahla also investigated with the diesel-ethanol blends on a diesel engine and conclude that ethanol is one of the suitable alternate fuels for a diesel engine. Their results said that when compared with diesel, the SFC was increased with ethanol blends due to its lower heating value, BTE was less but it is increasing with load, where as the emissions like $\mathrm{CO}, \mathrm{HC}$ were decreasing slightly with increase in blends.[11-14]

\section{FUEL SAMPLES AND ITS PREPARATION}

The fuels used in this present experiment are diesel and ethanol of purity $99 \%$. In this experiment, pure diesel was taken as a base fuel and a nano particle carbon nanotubes (CNT) was chosen to make diesel-ethanol-nano blends. The ethanol was blended with diesel on the basis of volume and CNT of 50ppm is added to each blend. Totally, three blends were prepared, which are E1050CNT (ethanol 10\%, diesel 90\%, 50ppm CNT), E2050CNT (ethanol 20\%, diesel 80\%, 50ppm CNT) and E3050CNT (ethanol 30\%, diesel 70\%, 50ppm CNT). The blends were made with the help of magnetic stirrer. The stirring was done until the mixture was homogeneous. To avoid the phase separation of mixture n-butanol was chosen as an additive and $6 \%$ of n-butanol was added in each blend. To mix the nano particles in the fuel blends, sonication was done with the help of ultrasonicator for a period of 1 hour for each blend. The ultrasonicator generator produces high voltage of energy pulses with a frequency of $20 \mathrm{kHz}$; therefore, these nanoparticles will disperse into the fuel blends easily, without settling down. A quantity of 50ppm (50mg) CNT is added to each blend. 
Table 1: Properties of Tested Fuels

\begin{tabular}{|l|c|c|}
\hline \multicolumn{1}{|c|}{ Property } & Diesel & Ethanol \\
\hline Density at $20^{\circ} \mathrm{c}\left(\mathrm{kg} / \mathrm{m}^{3}\right)$ & 836 & 787 \\
\hline Specific Gravity at $20^{\circ} \mathrm{c}$ & 0.80 & 0.795 \\
\hline Kinematic viscosity at $40^{\circ} \mathrm{c}\left(\mathrm{mm}^{2} / \mathrm{s}\right)$ & 2.7 & 1.2 \\
\hline Calorific value $(\mathrm{kj} / \mathrm{kg})$ & 42,500 & 26,400 \\
\hline Cetane no & 50 & $5-8$ \\
\hline
\end{tabular}

\section{EXPERIMENT SETUP AND ITS DESCRIPTION}

The experiments were conducted on the 4- stroke, single cylinder, water cooling high speed DI diesel engine as shown in the figure, to evaluate its performance and emission characteristics. The specifications of the tested engine setup are presented in Table 2. A rope brake dynamometer was arranged to load the engine to find out its performance at various loads. The rate of flow of the fuel was determined by observing the time taken for fuel consumption of a volume of 10cc through a burette with stopwatch. The engine exhaust gas emission characteristics like carbon monoxide (CO), unburned hydro carbons $(\mathrm{HC})$, carbon dioxide $\left(\mathrm{CO}_{2}\right)$, and oxides of nitrogen $\left(\mathrm{NO}_{\mathrm{X}}\right)$ were measured by using an INDUS 5gasanalyzer.

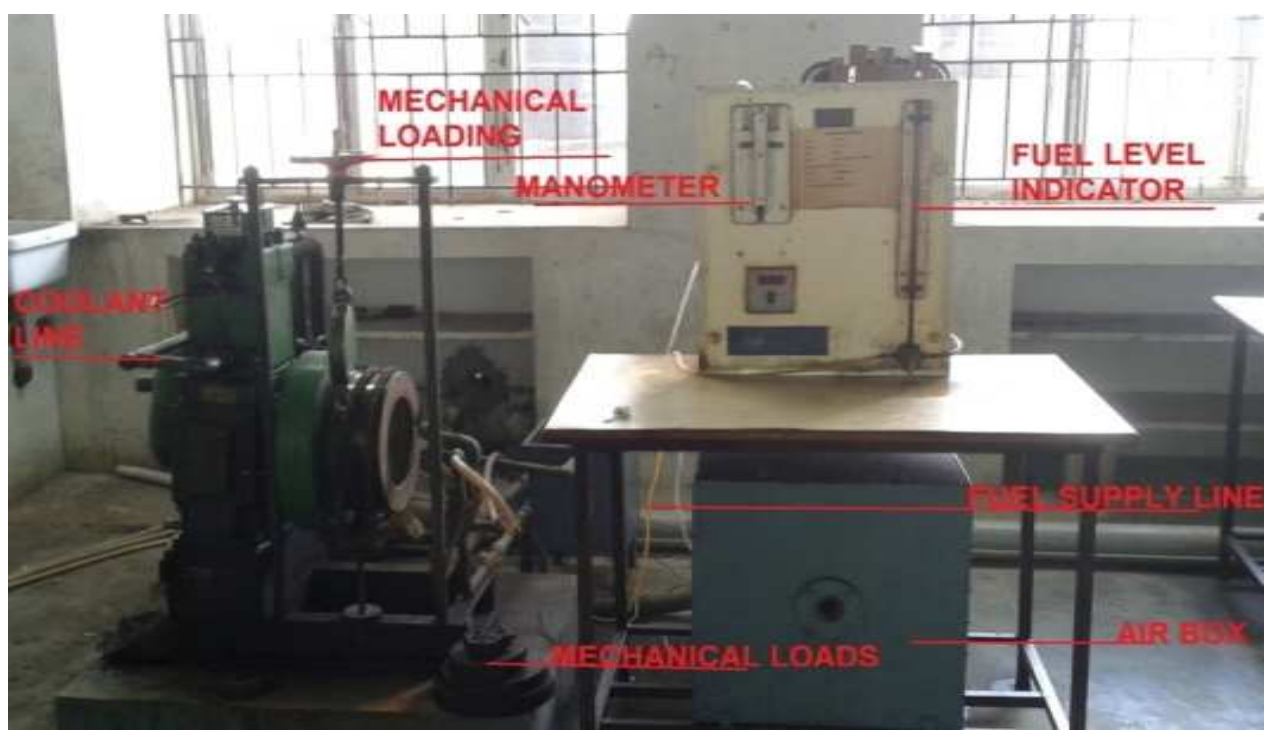

Figure 1 Experimental Set Up

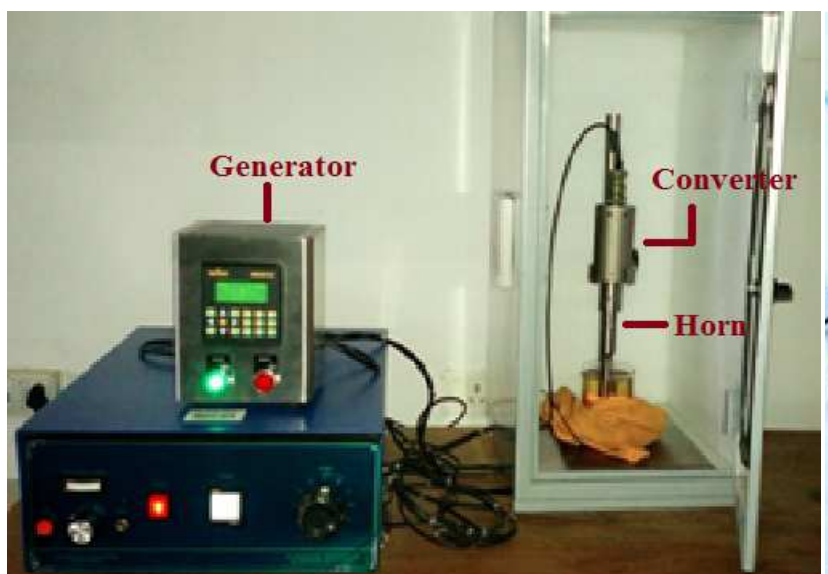

Figure 2: Ultrasonicator

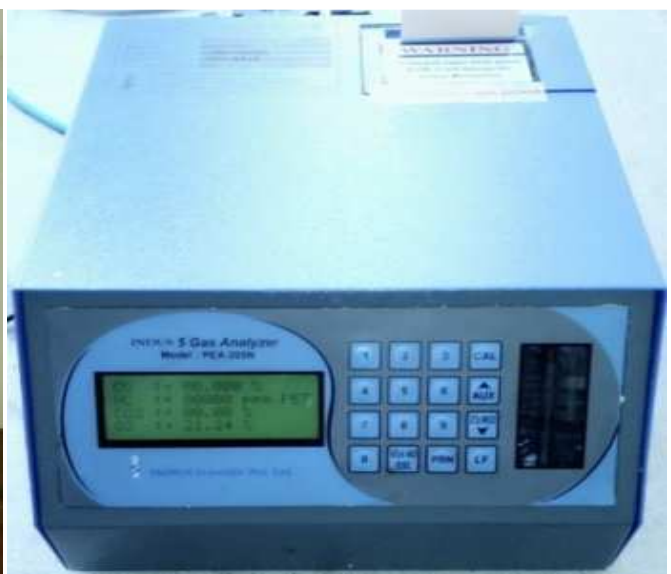

Figure 3: Indus 5 Gas Analyzer 
Table 2: Technical Specifications of the Engine

\begin{tabular}{|l|l|}
\hline \multicolumn{1}{|c|}{ Type of Engine } & \multicolumn{1}{|c|}{$\begin{array}{c}\text { Four Stroke Vertical, Water Cooled, Single } \\
\text { Cylinder, High Speed Diesel Engine }\end{array}$} \\
\hline Model & Kirloskar AV1 \\
\hline Cylinder Bore x Stroke (mm) & $80 \mathrm{~mm} \mathrm{X} \mathrm{110} \mathrm{mm}$ \\
\hline Compression ratio & $16.5: 1$ \\
\hline Brake power & $3.75 \mathrm{Kw}$ \\
\hline Speed & $1500 \mathrm{rpm}$ \\
\hline Injection pressure & 200 bar \\
\hline Load type & Mechanical \\
\hline
\end{tabular}

\section{EXPERIMENTAL PROCEDURE}

The experiment was conducted on the engine with diesel and blends of ethanol E1050CNT, E2050CNT and E3050CNT. At first, the load test was conducted with all the test samples at the loads of 0, 3, 6, 9 and $12 \mathrm{~kg}$. The time taken for 10cc of fuel consumption was noted down with the help of stop watch for each load for all the samples, and simultaneously, the corresponding readings of exhaust emissions like $\mathrm{CO}, \mathrm{HC}, \mathrm{CO}_{2}$, and $\mathrm{NO}_{\mathrm{X}}$ were also noted down and set to zero before each cycle. All the readings were tabulated in detail to calculate the brake thermal efficiency, specific fuel consumption. Later, the graphs were plotted between loads and emissions, performance parameters for comparative analysis.

\section{RESULTS AND DISCUSSIONS}

\section{Specific Fuel Consumption (SFC)}

Specific fuel consumption is one of the performance parameters, which provides the quantity of fuel consumed at various conditions. It can be calculated by doing the ratio of mass flow rate of fuel in $\mathrm{kg}$ per kwhr and brake power in $\mathrm{kw}$. The figure 4 shows the trend of SFC with respect to load. From this graph, it is pointed out that among all the blends, the SFC is increasing with increasing the percentage of ethanol, when compared with diesel at all the different loads. It is mainly due to the lesser calorific value of ethanol and diesel blends. Among all the blends with E10CNT50, the SFC is slightly decreased than diesel. The least SFC is with E10CNT50 blend at $12 \mathrm{~kg}$ load by a value of $0.325 \mathrm{~kg} / \mathrm{kwhr}$, whereas for the diesel it is $0.351 \mathrm{~kg} / \mathrm{kwhr}$.

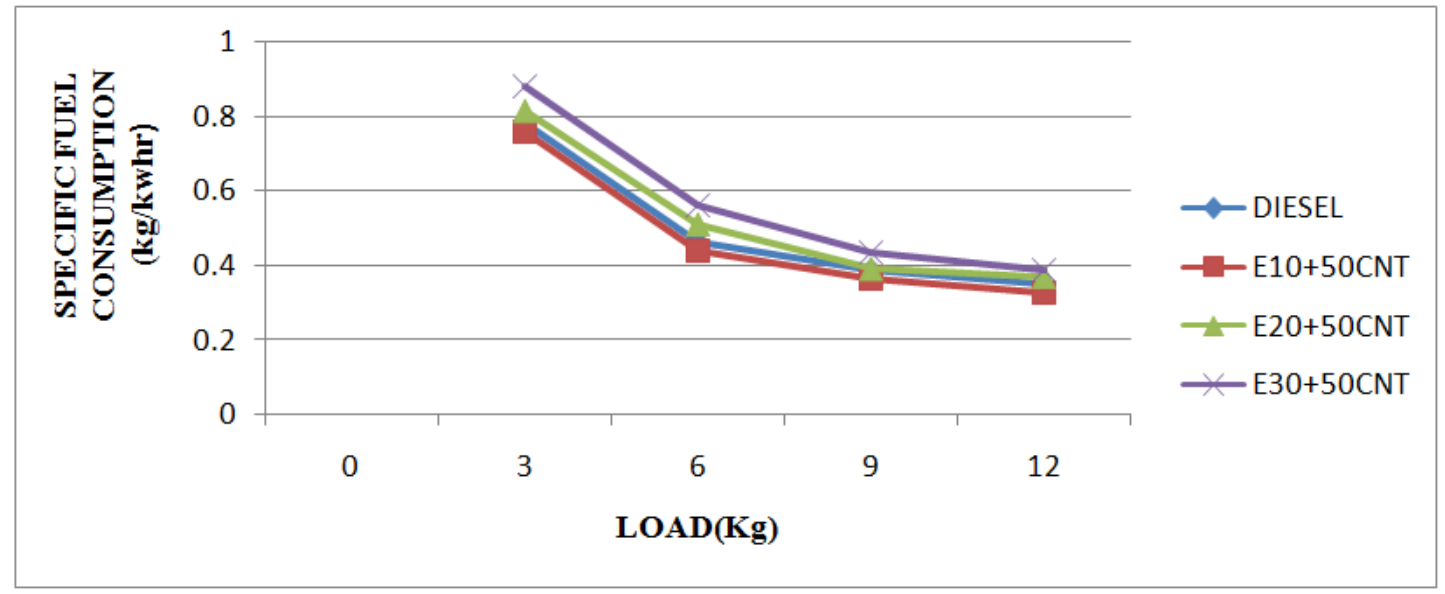

Figure 4: Shows Specific Fuel Consumption Vs Load 


\section{Brake Thermal Efficiency (BTE)}

The brake specific fuel consumption is also an important parameter for evaluating the engine performance in narrow manner. It can be find out by doing the ratio of brake power and energy produced by consuming the fuel. From the graph plotted between load and brake thermal efficiency for diesel and nano-ethanol-diesel blends, we can say that the BTE is slightly fluctuating with increase in percentage of ethanol in blends for all the loads. But, it is increased with increasing the load for all the tested fuel samples. The maximum efficiency is obtained with E10CNT50 at $12 \mathrm{~kg}$ load, when compared with both diesel and remaining blends and the respected values are 24.67, 24.09, 25.48, 25.61\%.

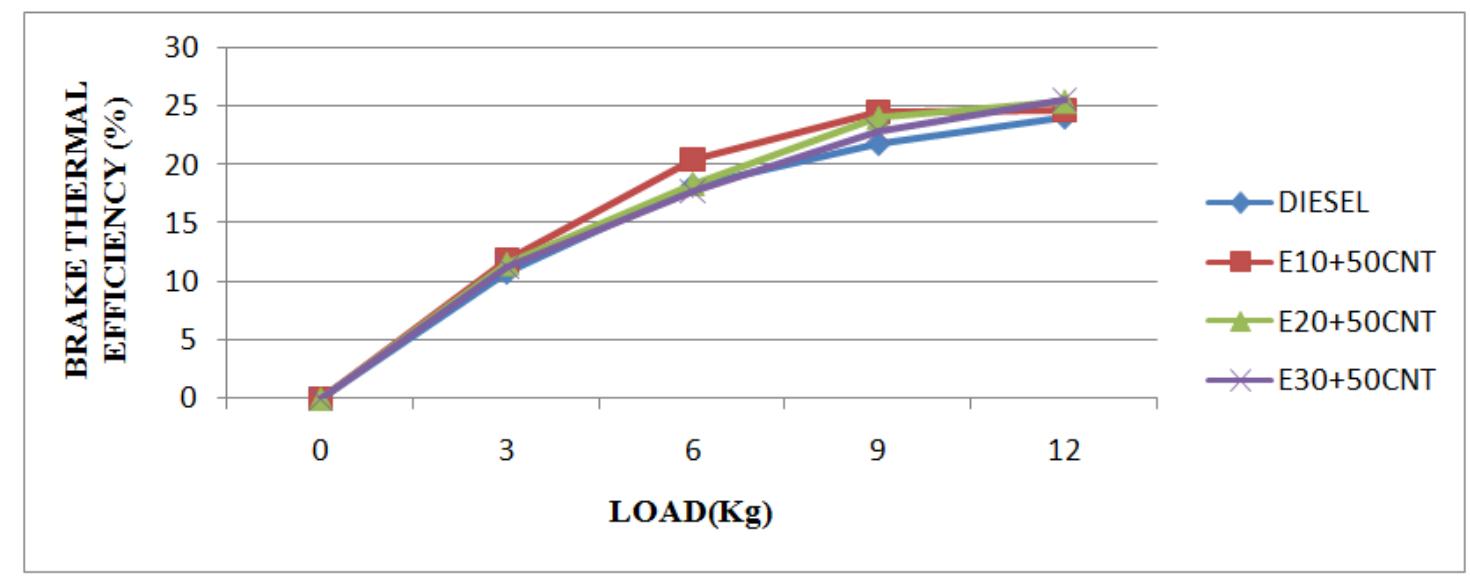

Figure 5: Shows Brake Thermal Efficiency Vs Load

\section{Carbon Monoxide (CO)}

The carbon monoxide is the harmful emission among the other exhaust gases. The CO emission is mainly because of the incomplete combustion. The graph is plotted between CO and load for all the tested fuel samples. With the help of this graph, we can clearly identify that the $\mathrm{CO}$ emissions are more with diesel than nano-diesel-ethanol blends at all the loads. Another point was noticed that with increasing the ethanol percentage in diesel, the CO is decreasing. Therefore, lesser CO emissions are obtained for the blend E30CNT50, when compared with diesel and other blends and the respected values are.012, $0.014,0.013$ and $0.013 \%$. But at $12 \mathrm{~kg}$ load, the $\mathrm{CO}$ emissions are less when compared with other load conditions for all the tested fuels.

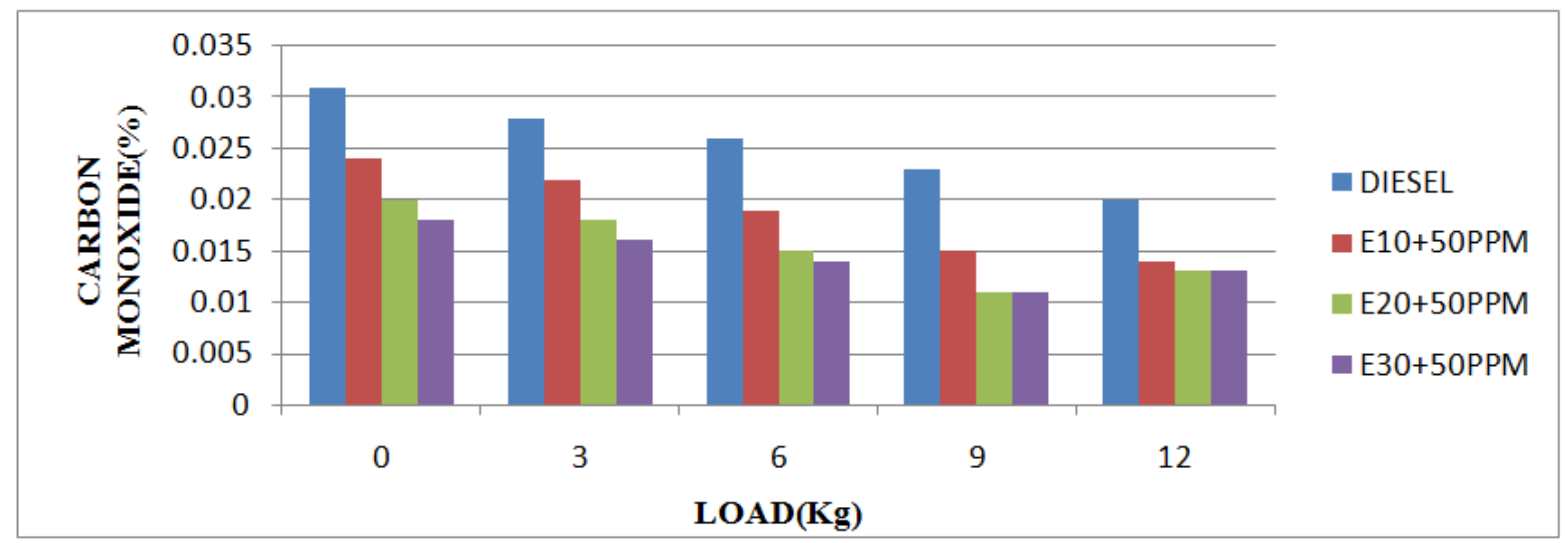

Figure 6: Shows Carbon Monoxides Load 


\section{Carbon Dioxide $\left(\mathrm{CO}_{2}\right)$}

The carbon dioxide is the green house gas, so, our wish is to get the lower values than diesel among blends of nano-ethanol-diesel. The graph is plotted between load and $\mathrm{CO}_{2}$ for various blends and at different loads to know the trends of carbon dioxide emission. From the graph, it is observed that the $\mathrm{CO}_{2}$ emissions are increasing with increase in load. But, $\mathrm{CO}_{2}$ is reducing with increasing the quantity of ethanol in blends. Among all the test samples, the least $\mathrm{CO}_{2}$ is for E30CNT50, when compared with diesel and remaining blends at no load condition. The respected values of $\mathrm{CO}_{2}$ at this condition are 2.5, 1.6, 1.4 and 1\% for diesel, E10, E20 and E30 nano blends. Due to the mixing of nano particles in the blends of ethanol and diesel, the $\mathrm{CO}_{2}$ is decreasing.

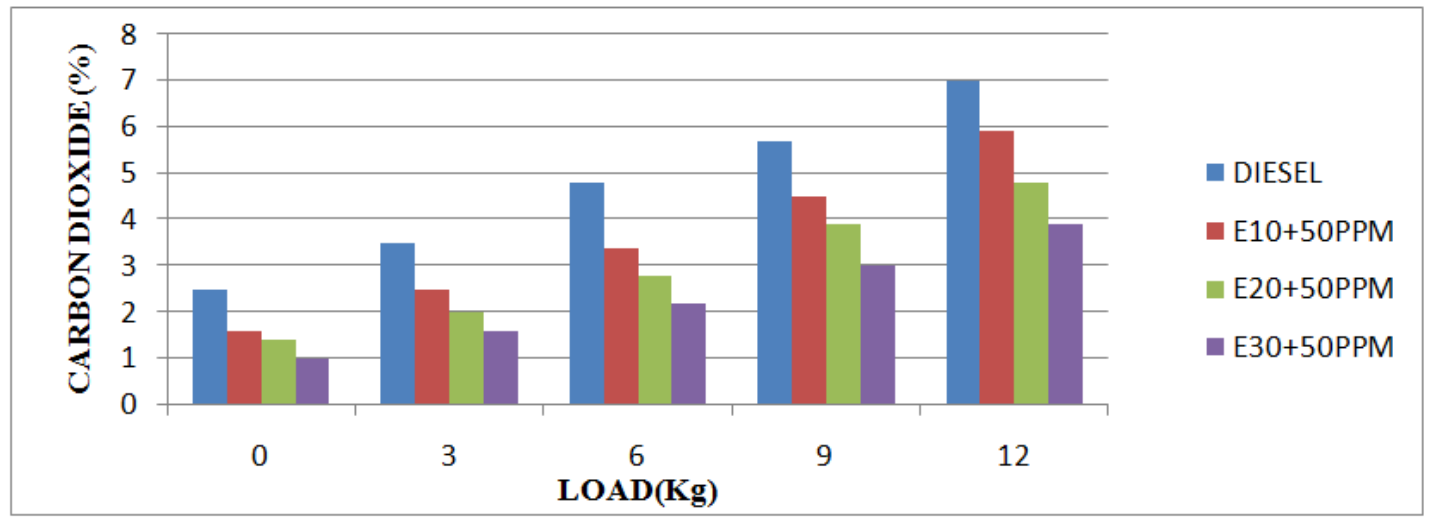

Figure 7: Shows Carbon Dioxides Load

\section{Hydro Carbon (HC)}

The un-burnt hydrocarbons are the emissions, mainly caused due to lack of oxygen in the combustion chamber. The graph was plotted between HC and loads for the tested fuel samples to analyze its quantity at various conditions. From this experiment, the graph shows that the HC emissions first decreases with increase in load up to half load condition and then increases up to full load. But, $\mathrm{HC}$ is reducing with increasing the quantity of ethanol in blends. The least HC is occurred with E30CNT50 at half load condition among all the fuel samples and the maximum HC is for diesel at no load condition when compared with all the blends. The respected values of HC for diesel, E10, E20, E30 nano blends at the $6 \mathrm{~kg}$ load are 32, 23, 16 and 10 ppm.

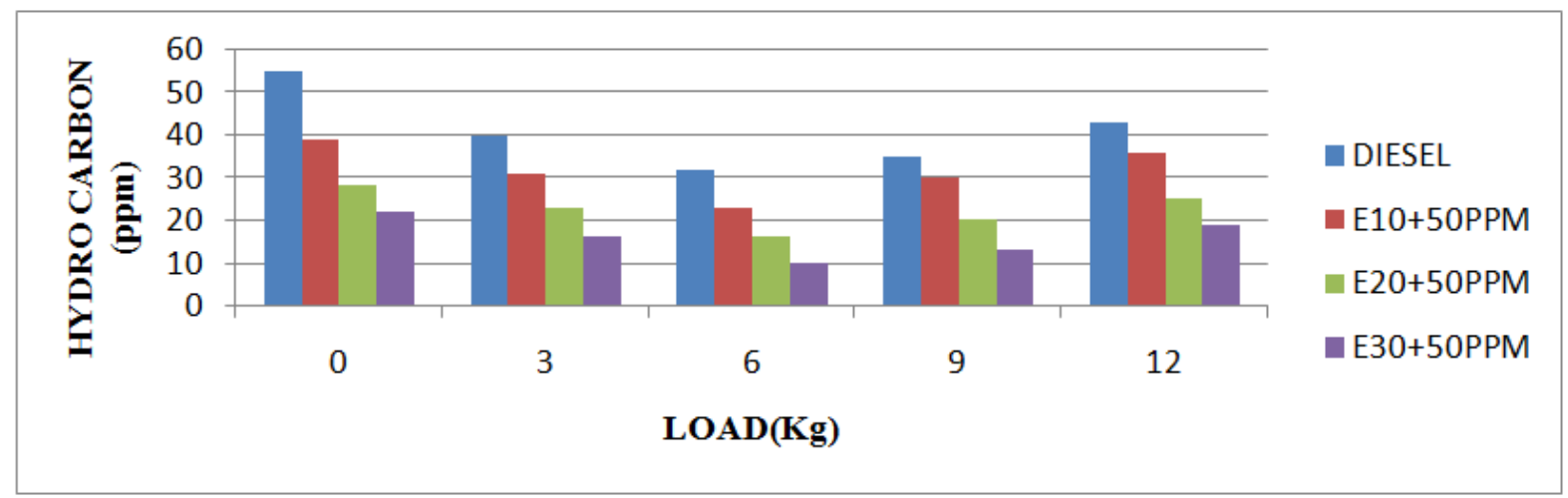

Figure 8: Shows Hydro Carbon Vs Load 


\section{Oxides of Nitrogen $\left(\mathrm{NO}_{\mathrm{X}}\right)$}

The oxides of nitrogen are mainly due to the higher temperatures of the exhaust gases. Therefore, the $\mathrm{NO}_{\mathrm{X}}$ emissions are more with ethanol blends due to its large heating value. By adding the ethanol to the diesel, the calorific value is decreased; so that consumption of fuel increased, thereby the temperatures will be raised. The graph is plotted between the oxides of nitrogen and load with diesel and nano-ethanol-diesel blends to make comparison. From the columns of graph, it is observed that the $\mathrm{NO}_{\mathrm{X}}$ emissions are nill at no load condition for all the test samples. But, at the remaining loads, $\mathrm{NO}_{\mathrm{X}}$ is increasing with increasing the quantity of ethanol in the blends, when compared with diesel. But, another important thing here observed is, with E10+50CNT, the $\mathrm{NO}_{\mathrm{X}}$ emissions are less at all loads when compared with diesel, E20, E30 nano blends, the respected values at $3 \mathrm{~kg}$ load are 30, 35, 40 and $50 \mathrm{ppm}$.

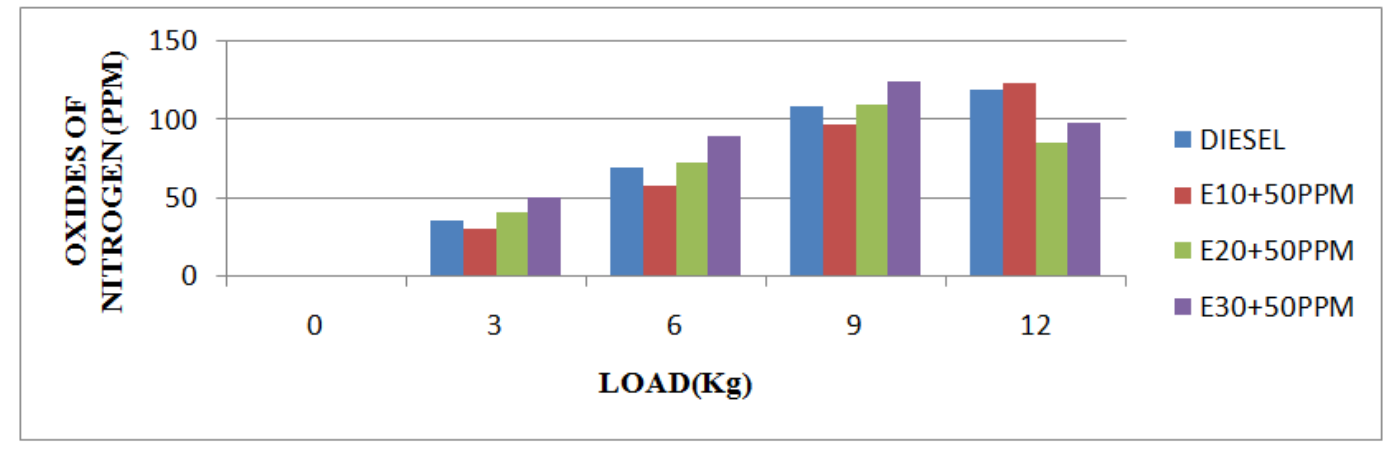

Figure 9: Shows Oxides of Nitrogen Vs Load

\section{CONCLUSIONS}

In this experiment, ethanol and diesel blends with a proportion of E10, E20and E30 along with nano particle carbon nano tubes was used to determine the output parameters like SFC, BTE and exhaust gas characteristics of a four stroke single cylinder high speed diesel engine. A quantity of $50 \mathrm{ppm}$ of carbon nano tubes (CNT) is added to all the ethanol-diesel blends at a constant engine speed of $1500 \mathrm{rpm}$ under the loads of 0, 3, 6,9 and 12kg. An additive n-butanol is added to avoid the layer separation between the diesel ethanol blends. From the experiment, the following results are obtained.

- The specific fuel consumption is slightly more with the diesel-ethanol-nano blends than diesel. SFC is slightly increasing with increase in ethanol quantity in diesel of a blend. But, the SFC is decreasing with increasing the load for all the tested fuel samples. The least SFC is obtained with E10CNT50 blend at $12 \mathrm{~kg}$ load by a value of $0.325 \mathrm{~kg} / \mathrm{kwhr}$, whereas for the diesel, it is $0.351 \mathrm{~kg} / \mathrm{kwhr}$.

- The brake thermal efficiency is increasing with increasing the load for all the tested fuel samples. But, it is slightly fluctuating with increasing the quantity of ethanol in blends. Mostly, it is decreasing with increase in proportion of ethanol. But, the maximum BTE is obtained for E10+50CNT at $12 \mathrm{~kg}$ load among all the samples.

- The carbon monoxide emission is reducing with increasing both the load and percentage of ethanol in the blend ratio. The least $\mathrm{CO}$ emissions are obtained with $\mathrm{E} 30+50 \mathrm{CNT}$ at higher loads.

- The carbon dioxide is increasing with increasing the load for all the tested fuel samples. But which is reducing with raising the proportion of ethanol in the blend ratio. The minimum $\mathrm{CO}_{2}$ emissions are obtained at no load condition with all the tested fuels, when compared with other loads, among which, it is minimum for 


\section{E30+50CNT.}

- The un-burnt hydrocarbons are greatly decreased with increasing the proportion of ethanol in the blends. But, the $\mathrm{HC}$ is highly decreased at half load conditions. The minimum HC is obtained at $6 \mathrm{~kg}$ load for E30+CNT sample.

- The oxides of nitrogen are zero at no load condition for all the test samples. But, the $\mathrm{NO}_{\mathrm{X}}$ is increasing with increasing both the load and ratio of ethanol in the blends. $\mathrm{NO}_{\mathrm{X}}$ is highly increased at greater loads.

\section{REFERENCES}

1. Hosseini, S. H., Taghizadeh-Alisaraei, A., Ghobadian, B., \& Abbaszadeh-Mayvan, A. (2017). Performance and emission characteristics of a CI engine fuelled with carbon nanotubes and diesel-biodiesel blends. Renewable Energy, 111, $201-213$.

2. El-Seesy, A. I., Abdel-Rahman, A. K., Bady, M., \& Ookawara, S. (2017). Performance, combustion, and emission characteristics of a diesel engine fueled by biodiesel-diesel mixtures with multi-walled carbon nanotubes additives. Energy Conversion and Management, 135, 373-393.

3. Parthasarathi, R., Gowri, S., \& Saravanan, C. G. (2014). EFFECTS OF ETHANOL-DIESEL EMULSIONS ON THE PERFORMANCE, COMBUSTION AND EMISSION CHARACTERISTICS OF DI DIESEL ENGINE. American Journal of Applied Sciences, 11(4), 592.

4. Selvan, V. A. M., Anand, R. B., \& Udayakumar, M. (2009). Effects of cerium oxide nanoparticle addition in diesel and dieselbiodiesel-ethanol blends on the performance and emission characteristics of a CI engine. J Eng Appl Sci, 4(7), 1819-6608.

5. Putrasari, Y., Nur, A., \& Muharam, A. (2013). Performance and emission characteristic on a two cylinder DI diesel engine fuelled with ethanol-diesel blends. Energy Procedia, 32, 21-30.

6. Gomasta, S., \& Mahla, S. K. (2012). An experimental investigation of ethanol blended diesel fuel on engine performance and emission of a diesel engine. International Journal on Emerging Technologies, 3(1), 74-79.

7. Muddada Venkatesh, K., and A. Lakshmu Naidu. "ANALYSIS FOR NATURAL CIRCULATION LOOP." Asia Pacific Journal of Research ISSN (Print) 2320: 5504.

8. Lei, J., Bi, Y., \& Shen, L. (2010). Performance and emission characteristics of diesel engine fueled with ethanol-diesel blends in different altitude regions. BioMed Research International, 2011.

9. Pugazhvadivu, M. (2009). Studies on the effect of ethanol addition to biodiesel: Performance and emissions of a diesel engine. Indian Journal of Science and Technology, 2(11), 23-26.

10. Sandalcl, T., Karagöz, Y., Orak, E., \& Yüksek, L. (2014). An Experimental Investigation of Ethanol-Diesel Blends on Performance and Exhaust Emissions of Diesel Engines. Advances in Mechanical Engineering, 6, 409739.

11. Rao, M. S., Venkatesh, N., \& Naidu, A. L. A Review on Performance of Diesel Engines by using Biodiesel blends from Different oils.

12. Naidu, A. L., \& Rao, P. R. A Review on Chemical Properties of Biodiesel from Sorghum Oils.

13. Saravanakumar, A., A. Avinash, and R. Saravanakumar. "Optimization of biodiesel production from Pungamia oil by Taguchi's technique." Energy Sources, Part A: Recovery, Utilization, and Environmental Effects 38.17 (2016): 2524-2529.

14. S Chiranjeeva Rao, A. Saravanakumar, G Chandra Sekhar, Influence of Nano Added MME Blends on CI Engine Based on DOE Concept, International Journal of Mechanical Engineering and Technology, Volume, 8, Issue-7, Pages 860-868, 2017. 